Article

\title{
Ga/HZSM-5 Catalysed Acetic Acid Ketonisation for Upgrading of Biomass Pyrolysis Vapours
}

\author{
Hessam Jahangiri ${ }^{1,2,3}{ }^{(0)}$, Amin Osatiashtiani ${ }^{3}{ }^{(0)}$, Miloud Ouadi ${ }^{1}$, Andreas Hornung ${ }^{1,4,5}$, \\ Adam F. Lee ${ }^{6, *(1)}$ and Karen Wilson ${ }^{6, *}$ \\ 1 School of Chemical Engineering, University of Birmingham, Birmingham B15 2TT, UK; \\ h.jahangiri@bham.ac.uk (H.J.); m.ouadi@bham.ac.uk (M.O.); andreas.hornung@umsicht.fraunhofer.de (A.H.) \\ 2 School of Water, Energy and Environment, Cranfield University, Cranfield MK43 0AL, UK \\ 3 European Bioenergy Research Institute, Aston University, Birmingham B4 7ET, UK; \\ a.osatiashtiani@aston.ac.uk \\ 4 Fraunhofer UMSICHT, Fraunhofer Institute for Environmental, Safety and Energy Technology, An der \\ Maxhütte 1, 92237 Sulzbach-Rosenberg, Germany \\ 5 Friedrich-Alexander University Erlangen-Nuremberg, Schlossplatz 4, 91054 Erlangen, Germany \\ 6 Applied Chemistry \& Environmental Science, RMIT University, Melbourne, VIC 3000, Australia \\ * Correspondence: adam.lee2@rmit.edu.au (A.F.L.); karen.wilson2@rmit.edu.au (K.W.); \\ Tel.: +61-399-252-623 (A.F.L.); +61-(03)-9925-2122 (K.W.)
}

Received: 19 September 2019; Accepted: 5 October 2019; Published: 11 October 2019

check for updates

\begin{abstract}
Pyrolysis bio-oils contain significant amounts of carboxylic acids which limit their utility as biofuels. Ketonisation of carboxylic acids within biomass pyrolysis vapours is a potential route to upgrade the energy content and stability of the resulting bio-oil condensate, but requires active, selective and coke-resistant solid acid catalysts. Here we explore the vapour phase ketonisation of acetic acid over Ga-doped HZSM-5. Weak Lewis acid sites were identified as the active species responsible for acetic acid ketonisation to acetone at $350{ }^{\circ} \mathrm{C}$ and $400{ }^{\circ} \mathrm{C}$. Turnover frequencies were proportional to Ga loading, reaching $\sim 6 \mathrm{~min}^{-1}$ at $400{ }^{\circ} \mathrm{C}$ for $10 \mathrm{Ga} / \mathrm{HZSM}-5$. Selectivity to the desired acetone product correlated with the weak:strong acid site ratio, being favoured over weak Lewis acid sites and reaching 30\% for 10Ga/HZSM-5. Strong Brønsted acidity promoted competing unselective reactions and carbon laydown. 10Ga/HZSM-5 exhibited good stability for over $5 \mathrm{~h}$ on-stream acetic acid ketonisation.
\end{abstract}

Keywords: pyrolysis; ketonisation; bio-oil; turnover frequencies (TOFs)

\section{Introduction}

Hydrocarbons sourced from non-edible or waste lignocellulosic or algal biomass are an attractive source of sustainable liquid transportation fuels to mitigate current dependence on fossil fuels and associated anthropogenic climate change [1,2]. However, biomass-derived fuels are incompatible with existing distribution infrastructure and vehicle engines without (catalytic) upgrading to improve their physicochemical properties [2,3]. A range of thermochemical technologies exist for bio-oil production, including hydrothermal liquefaction [4,5] and pyrolysis [6,7], or gasification [8,9] and subsequent Fischer-Tropsch synthesis [10,11]. Pyrolysis routes have gained particular attention over the past 30 years, offering a high liquid (bio-oil) yield which can be used directly as a drop-in fuel, blended with conventional diesel, or as an efficient energy vector [12,13]. Pyrolysis bio-oils are mixtures of oxygenated compounds which typically comprise phenolics, furanics, carboxylic acids and other small oxygenates whose composition varies with biomass source and processing $[6,14,15]$. The high oxygen content of crude bio-oils results in a heating value half that of petroleum-derived fuels, while the presence of carboxylic acids renders the oils corrosive ( $\mathrm{pH} 2-3)$ [15] and chemically unstable due to 
presence of small reactive oxygenates (e.g., unsaturated aldehydes) which may undergo acid-catalysed polymerisation [2]. Crude bio-oils must therefore be upgraded to remove corrosive components and improve stability prior to subsequent hydrodeoxygenation to improve their calorific value.

A range of catalytic routes exist for upgrading pyrolysis bio-oils, including esterification [16], hydrodeoxygenation (HDO) [17], aldol condensation [18] and ketonisation [19]. Each route has advantages and disadvantages. For example, esterification operates at low temperature in the liquid phase but requires an external source of short-chain alcohols, and produces water by-product which must be separated [20]. HDO is effective for the production of cyclic and aliphatic alkanes as liquid fuels, but requires a renewable $\mathrm{H}_{2}$ input and precious metal catalysts that are stable in (often acidic) bio-oils and coke-resistant [21]. Aldol condensation stabilises bio-oils by converting some reactive oxygenates over solid base catalysts, but does not address the intrinsic acidity of bio-oils that can deactivate HDO catalysts [22]. Ketonisation affords an intermediate deoxygenation step that can be close-coupled to a pyrolysis reactor to upgrade vapours before then condense into a bio-oil, thereby improving bio-oil acidity, and achieving partial deoxygenation [19], although it is also accompanied by a small loss of carbon as $\mathrm{CO}_{2}$. Ketonisation [22-24], takes place through the condensation of two carboxylic (e.g., acetic) acid molecules to form a ketone (e.g., acetone), $\mathrm{CO}_{2}$ and $\mathrm{H}_{2} \mathrm{O}$ (Figure 1). An important advantage of ketonisation over esterification for acid neutralisation is that the former can be performed in the vapour phase without additional reactants, thus enabling close-coupling to a pyrolysis reactor to upgrade bio-oil vapours prior to their condensation as a bio-oil [24,25]. Ketonisation also facilitates bio-oil deoxygenation and concomitant hydrocarbon chain growth [26], and hence improves the calorific value of the resulting condensate (in addition to its $\mathrm{pH}$ and stability).

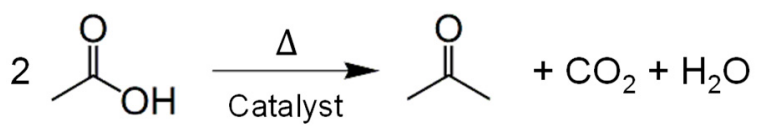

Figure 1. Acetic acid ketonisation.

Ketonisation is widely studied in organic synthesis [25,27], being catalysed by diverse heterogeneous catalysts including alkaline earth metal oxides such as $\mathrm{BaO}, \mathrm{MgO}$ [28,29], transition metal oxides including $\mathrm{MnO}_{2}[24,30,31], \mathrm{TiO}_{2}[32,33], \mathrm{Fe}_{3} \mathrm{O}_{4}[22,24,34], \mathrm{CeO}_{2}[35,36]$ and $\mathrm{ZrO}_{2}[37,38]$ and actinide oxides such as $\mathrm{ThO}_{2}$ [39]. The mechanism of ketonisation and corresponding sensitivity to catalyst properties remains the subject of ongoing debate $[25,40]$. Ketonisation over basic and reducible oxide catalysts proceeds via two distinct pathways depending on the lattice energy of the metal oxide, with lower energy lattice (stronger bases) forming stable carboxylates that thermally decompose at elevated temperature $\left(>420^{\circ} \mathrm{C}\right)[41]$ to yield ketones, whereas higher energy lattices favour a lower temperature surface catalysed route [25]. However, there are fewer reports of carboxylic acid ketonisation over zeolites, being limited to HZSM-5, HZSM-11, HZSM-34, HZSM-35, mordenite, erionite and zeolite Beta. Of these, HZSM-5(100) is the most favourable for acetic acid ketonisation to acetone [42], being very selective to xylenols and acetone at moderate reaction temperatures $\left(320^{\circ} \mathrm{C}\right)$ and forming acetone as the major product $>350^{\circ} \mathrm{C}$ [42]. Zeolite modification by transition metals and lanthanides such as $\mathrm{Ce}, \mathrm{Co}, \mathrm{Ni}$ and $\mathrm{Ga}$ increases aromatic product yields during catalytic pyrolysis [43-45], however to our knowledge Ga-promoted zeolites have never been investigated for carboxylic acid ketonisation. Gallium can be introduced into zeolites by incipient wetness impregnation and ion exchange [46], although the choice of preparation method had little impact on aromatic products from Ga/HZSM-5-catalysed fast pyrolysis [46].

HZSM-5 is an attractive catalyst for acetic acid ketonisation, owing to its corrosion resistance, high surface area, commercial availability and ability to stabilise undercoordinated cations and hence tune surface composition and resulting catalytic performance [25]. The presence of strongly acidic protons in zeolites reportedly promotes the formation of surface acyl species, rather than carboxylates, following acid adsorption. Subsequent coupling of a carboxylic acid and surface acyl yields an acid anhydride, which in turn dissociates to liberate $\mathrm{CO}_{2}$ and a ketone as illustrated in Figure 2 [25,47], 
although Chang et al propose that ketonisation proceeds by nucleophilic attack of an acylium ion by adsorbed carboxylate [48]. The latter is similar to a ketene intermediate pathway, in with the acylium ion is directly formed by acid protonation and water loss [48]. The relationship between Lewis/Brønsted acid character and ketonisation activity/selectivity over zeolites remains poorly established.

1. Adsorption of carboxylic acid with elimination of water,

2. Surface acyl formation,

3. Surface adsorption of second carboxylic acid,

4. Coupling of adsorbed carboxylic acid with a surface acyl group to form an acid anhydride,

5. Adsorbed anhydride decomposition to form $\mathrm{CO}_{2}$ and acetone.

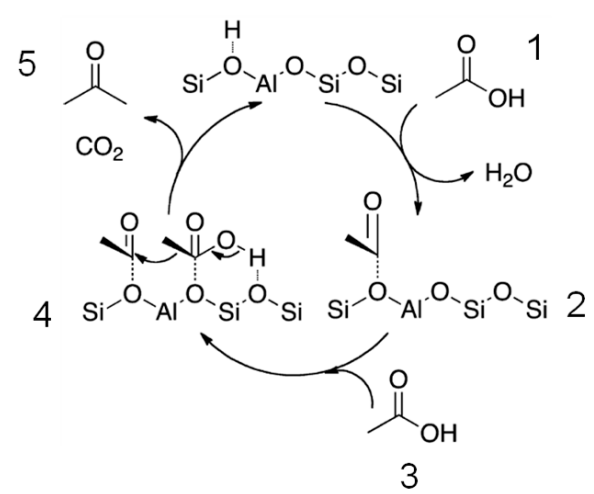

Figure 2. Proposed mechanism for acetic acid ketonisation to acetone over zeolites. Reproduced with permission from reference [47], Copyright (C) 2016, Elsevier.

Herein, we report the impact of Ga doping on the surface acidity of HZSM-5 and associated reactivity for the continuous vapour phase ketonisation of acetic acid to acetone. Activity and selectivity to acetone were proportional to Ga loading, reflecting the formation of weak Lewis acid sites and suppressed coking.

\section{Results and Discussion}

\subsection{Catalyst Characterisation}

Crystalline phases were characterised by powder X-ray diffraction (XRD). Figure S1 shows diffraction patterns for HZSM-5 as a function of Ga loadings to HZSM-5, and pure bulk $\mathrm{Ga}_{2} \mathrm{O}_{3}$. No reflections associated with gallium oxide phases were observed for any loadings, indicating either the presence of highly dispersed $\mathrm{Ga}_{2} \mathrm{O}_{3}$ nanoparticles throughout the HZSM- 5 pore network, or the exchange of $\mathrm{Ga}^{3+}$ with $\mathrm{Al}^{3+}$ ions in the framework (or protons at the surface of the zeolite). It is well documented that protons play an important role in regulating the interaction of metal oxides with zeolite surfaces $[49,50]$. Fang and co-workers report that impregnation favours the formation of $\mathrm{Ga}_{2} \mathrm{O}_{3}$ and small amounts of $\mathrm{GaO}^{+}$at surface of ZSM-5, thereby introducing weak Lewis acid sites [51]. In contrast ion-exchanged $\mathrm{Ga} / \mathrm{HZSM}-5$ prepared by refluxing the zeolite in aqueous $\mathrm{Ga}\left(\mathrm{NO}_{3}\right)_{3}$ at $70-100{ }^{\circ} \mathrm{C}[46,52]$ appears to favour framework dealumination through $\mathrm{Ga}$ ion-exchange. Although the latter syntheses resemble our impregnating conditions we cannot conclude whether Ga resides as surface $\mathrm{GaO}^{+}$clusters or within the zeolite framework. The reference gallium oxide was phase-pure monoclinic $\left(\mathrm{m}-\mathrm{Ga}_{2} \mathrm{O}_{3}\right)$ with reflections at $2 \theta=19.0^{\circ}, 30.4^{\circ}, 30.5^{\circ}, 31.8^{\circ}, 33.5^{\circ}, 35.2^{\circ}, 37.4^{\circ}, 38.5^{\circ}, 42.8^{\circ}$, $45.9^{\circ}, 48.7^{\circ}$ and $57.5^{\circ}[53,54]$. Crystallite sizes of the parent HZSM-5 (Table 1) were independent of Ga loading, and significantly smaller than the zeolite. Nitrogen porosimetry revealed type IV isotherms for $\mathrm{xGa} / \mathrm{HZSM}-5$ (Figure S2), with the observed mesoporosity attributed to interparticle voids [55]. Corresponding Brunauer-Emmett-Teller (BET) surface areas, total pore volumes and micropore volumes continuously decreased with increased Ga loading (Table 1), attributed to partial 
pore blockage, possibly as a result of extra-framework gallium deposition within the micropores [56]. Bulk $\mathrm{Ga}_{2} \mathrm{O}_{3}$ exhibited a very low surface area $<10 \mathrm{~m}^{2} \cdot \mathrm{g}^{-1}$.

Table 1. Elemental analysis and physicochemical properties of catalysts.

\begin{tabular}{|c|c|c|c|c|c|c|c|}
\hline Catalysts & $\begin{array}{c}\text { Ga } \\
\begin{array}{c}\text { Loading a } \\
/ w t \%\end{array}\end{array}$ & $\begin{array}{c}\mathrm{S}_{\mathrm{BET}} \\
/ \mathrm{m}^{2} \cdot \mathrm{g}^{-1}\end{array}$ & $\begin{array}{c}\mathrm{V}_{\text {Total }} \mathbf{b} \\
/ \mathrm{mL}^{-\mathbf{g}^{-1}}\end{array}$ & $\begin{array}{l}\mathrm{V}_{\text {micro }}{ }^{\mathrm{c}} \\
/ \mathrm{mL}^{-\mathrm{g}^{-1}}\end{array}$ & $\begin{array}{l}\text { Crystallite } \\
\text { Size }^{\mathrm{d}} \\
\text { /nm }\end{array}$ & $\begin{array}{c}\text { Acid } \\
\text { Loading } \\
\text { /mmol.g } \\
\text { mmol }^{-1}\end{array}$ & $\begin{array}{c}\text { Weak:Strong } \\
\text { Acid Site } \\
\text { Ratio }^{\mathrm{f}}\end{array}$ \\
\hline HZSM-5 & 0 & 427 & 0.294 & 0.141 & 65.7 & 1.13 & 0.29 \\
\hline $0.5 \mathrm{Ga} / \mathrm{HZSM}-5$ & 0.3 & 420 & 0.290 & 0.140 & 55.2 & 1.09 & 0.38 \\
\hline 3 Ga/HZSM-5 & 3.0 & 338 & 0.249 & 0.106 & 50.3 & 1.03 & 0.53 \\
\hline $10 \mathrm{Ga} / \mathrm{HZSM}-5$ & 9.0 & 313 & 0.210 & 0.099 & 62.6 & 0.80 & 0.83 \\
\hline $\mathrm{Ga}_{2} \mathrm{O}_{3}$ & 75 & 7.6 & 0.08 & - & 26.4 & 0.14 & 0.40 \\
\hline
\end{tabular}

${ }^{\mathrm{a}}$ ICP-OES, ${ }^{\mathrm{b}}$ total pore volume at $\mathrm{P} / \mathrm{Po}=0.98,{ }^{\mathrm{c}} \mathrm{t}$-plot method, ${ }^{\mathrm{d}} \mathrm{XRD},{ }^{\mathrm{e}}$ propylamine desorption, ${ }^{\mathrm{f}} \mathrm{XPS}$.

Elemental analysis revealed the surface Ga content was consistently lower than the bulk determined by XPS and ICP-AES analysis respectively (Table S1), consistent with the selective incorporation of gallium inside the HZSM-5 pore network. The formation of large $\mathrm{Ga}_{2} \mathrm{O}_{3}$ particles on the external surface of zeolite crystallites can be discounted due to the absence of associated XRD patterns. Note that the lower $\mathrm{Ga}$ surface versus bulk content for the $\mathrm{m}-\mathrm{Ga}_{2} \mathrm{O}_{3}$ reference reflects oxygen termination of gallium surfaces [57]. O 1s XP spectra of HZSM-5 revealed a single broad peak with a $533 \mathrm{eV}$ binding energy associated with $\mathrm{Si}-\mathrm{O}-\mathrm{Si}$ and $\mathrm{Si}-\mathrm{O}-\mathrm{Al}$ environments [58,59] (Figure 3a), which was unaffected by low levels of $\mathrm{Ga}$ doping, but shifted to lower binding energy for $10 \mathrm{Ga} / \mathrm{HZSM}-5$, approaching that of $\mathrm{Ga}_{2} \mathrm{O}_{3}$ at $530.7 \mathrm{eV}[60,61]$. A similar trend was observed for the $\mathrm{Ga} 2 \mathrm{p}_{3 / 2} \mathrm{XP}$ spectra (Figure $3 \mathrm{~b}$ ), which exhibited a single broad peak at $1119.0 \mathrm{eV}$ for low Ga loadings, whose binding energy decreased towards that of $\mathrm{m}-\mathrm{Ga}_{2} \mathrm{O}_{3}$ at $1117.9 \mathrm{eV}$ for $10 \mathrm{Ga} / \mathrm{HZSM}-5$ [62]. These data demonstrate that the local environment of gallium in HZSM- 5 is chemically distinct from that in bulk $\mathrm{Ga}_{2} \mathrm{O}_{3}$, consistent with either highly dispersed $\mathrm{Ga}_{2} \mathrm{O}_{3}$ nanoparticles, or ion-exchange of $\mathrm{Ga}^{3+}$ into the zeolite framework [62,63]. Corresponding $\mathrm{Al}$ and $\mathrm{Si} 2 \mathrm{p}$ XP spectra of $\times \mathrm{Ga} / \mathrm{HZSM}-5$ (Figure S3a,b) each evidenced a single chemical environment with respective binding energies of approximately $75.1 \mathrm{eV}$ and $103.8 \mathrm{eV}$, consistent with the literature for HZSM-5 [58,59]. Al and Si 2p peaks shifted to lower binding energy for 10Ga/HZSM-5 indicative of significant ion-exchange and concomitant formation of extra-framework alumina.
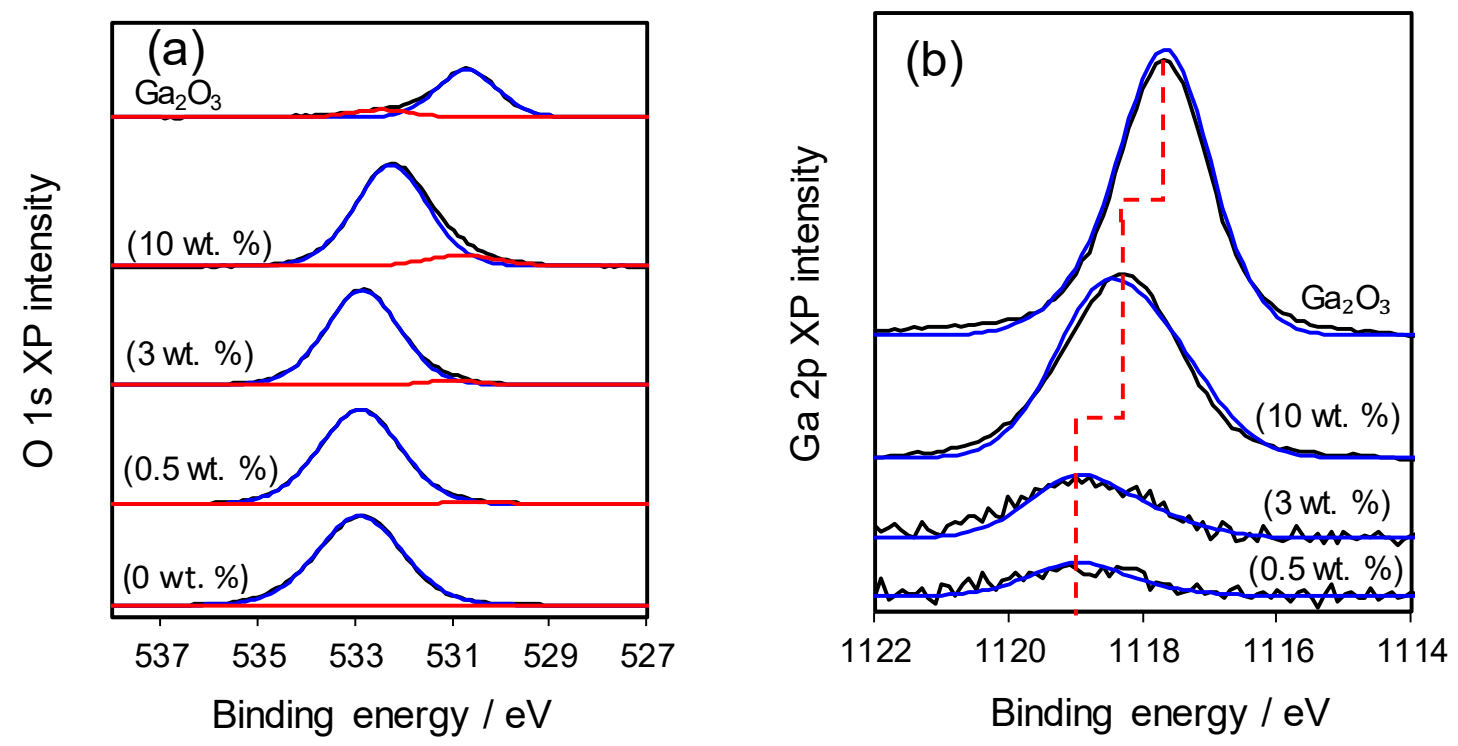

Figure 3. (a) $\mathrm{O} 1$ s and (b) $\mathrm{Ga} 2 \mathrm{p}$ XP spectra of $\times \mathrm{Ga} / \mathrm{HZSM}-5$ and $\mathrm{Ga}_{2} \mathrm{O}_{3}$.

The acid properties of $x \mathrm{Ga} / \mathrm{HZSM}-5$ and $\mathrm{m}-\mathrm{Ga}_{2} \mathrm{O}_{3}$ were first investigated by diffuse reflectance Fourier transform infrared spectroscopy (DRIFTS) following pyridine adsorption (Figure S4a). 
Strong bands at $1444 \mathrm{~cm}^{-1}$ and $1545 \mathrm{~cm}^{-1}$ were assigned to pyridine bound to Lewis and Brønsted acid sites respectively, the intense band at $1490 \mathrm{~cm}^{-1}$ to pyridine bound to both acid sites and the weak $1600 \mathrm{~cm}^{-1}$ band to pyridine bound to Lewis acid sites [56]. The relative Lewis/Brønsted acid character was quantified from the ratio of $1444 \mathrm{~cm}^{-1}$ and $1545 \mathrm{~cm}^{-1}$ band intensities (Figure S4b). The Lewis:Brønsted ratio exhibited a small increase for 10Ga/HZSM-5, in accordance with literature reports $[56,64,65]$. Corresponding DRIFTS for pyridine on $\mathrm{m}-\mathrm{Ga}_{2} \mathrm{O}_{3}$ revealed two weak bands at $1452 \mathrm{~cm}^{-1}$ and $1614 \mathrm{~cm}^{-1}$ indicative of pure Lewis acid character as previously reported [66,67]. Acid strength was subsequently probed by temperature-programmed reaction spectroscopy (TPRS) of propylamine. Reactively-formed propene (arising from propylamine decomposition over acid sites) was evolved in two desorptions at $\sim 480{ }^{\circ} \mathrm{C}$ and $\sim 540-555{ }^{\circ} \mathrm{C}$ associated with strong and weak acid sites respectively (Figure 4); the former possibly arising from high-index facets or defects [68,69]. The desorption temperature of both peaks was independent of Ga loading, however the ratio of weak:strong acid sites decreased monotonically reaching $\sim 0.83$ for $10 \mathrm{Ga} / \mathrm{HZSM}-5$. The decreased acid strength was consistent with ion-exchange of less electronegative $\mathrm{Ga}^{3+}$ for $\mathrm{Al}^{3+}$ into the zeolite surface, which is expected to decrease hydroxyl polarisation and hence Brønsted acid strength [70]. Acid site loadings and weak:strong acid site ratio respectively decreased and increased with Ga loading (Table 1 and Figure S5), however the total acid site density was approximately constant at $\sim 2.6 \mu \mathrm{mol} \cdot \mathrm{m}^{-2}$. The acid site density of $\mathrm{m}-\mathrm{Ga}_{2} \mathrm{O}_{3}$ was significantly higher at $18.4 \mu \mathrm{mol} \cdot \mathrm{m}^{-2}$, with a weak:strong acid site ratio of 0.40 akin to $0.5 \mathrm{Ga} / \mathrm{HZSM}-5$, however the absolute Ga loading was far lower than any of the xGa/HZSM-5 materials.

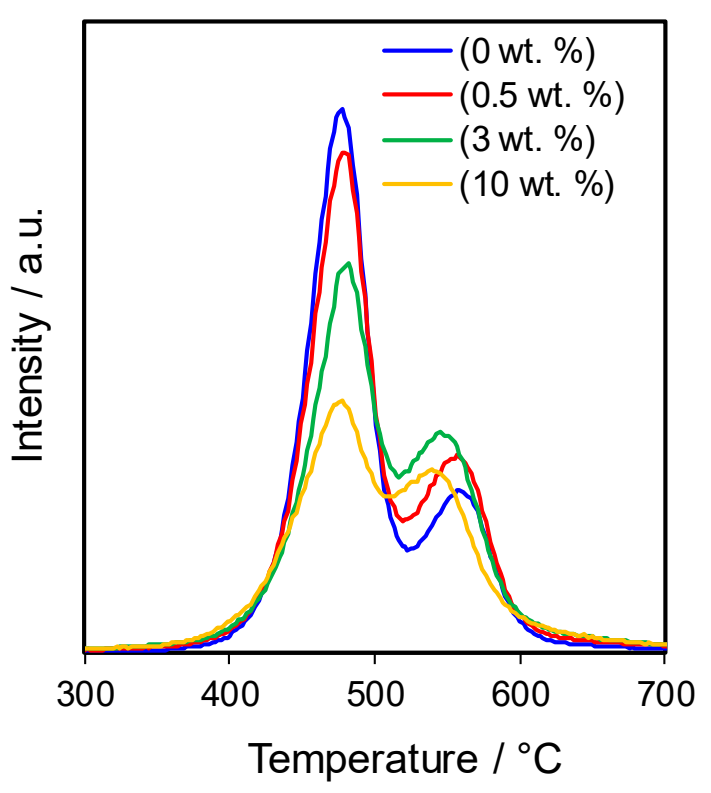

Figure 4. Reactively-formed propene from propylamine temperature-programmed reaction spectroscopy (TPRS) over xGa/HZSM-5.

\subsection{Catalytic Activity in Ketonisation}

Vapour phase acetic acid ketonisation was subsequently studied over $\times \mathrm{Ga} / \mathrm{HZSM}-5$ in a fixed-bed continuous flow reactor. Turnover frequencies (TOFs) were derived by normalising the steady state rate of acetic acid conversion to the acid site loadings from Table 1 . At $350{ }^{\circ} \mathrm{C}$, TOFs were almost independent of Ga loading, exhibiting only a small increase for 10Ga/HZSM-5. Increasing the reaction temperature to $400{ }^{\circ} \mathrm{C}$ increased TOFs for all catalysts as previously reported [19,71], with a monotonic rise with Ga loading now apparent (Figure 5). Catalytic reactivity mirrored the weak:strong acid site ratio for both reaction temperatures, indicating that ketonisation preferentially occurs over weak acid sites within $\times \mathrm{Ga} / \mathrm{HZSM}-5$. Limited deactivation $(<15 \%)$ was observed for $5 \mathrm{~h}$ on-stream for all $\mathrm{xGa} / \mathrm{HZSM}-5$ catalysts (Figure S6), attributed to pore/site-blocking by coke or strongly bound 
bidentate carboxylate species [72], or structural changes, whereas the $\mathrm{Ga}_{2} \mathrm{O}_{3}$ reference exhibited minimal deactivation. Powder XRD revealed negligible change zeolite structure following the reaction (Figure S7), however elemental analysis confirmed the presence of surface carbon post-reaction for all $\mathrm{xGa} / \mathrm{HZSM}-5$ catalysts (falling from $12 \mathrm{wt} \%$ for the parent HZSM- 5 and $\mathrm{xGa} / \mathrm{HZSM}-5$ samples to only $1 \mathrm{wt} \%$ for $\mathrm{Ga}_{2} \mathrm{O}_{3}$, Table S2).

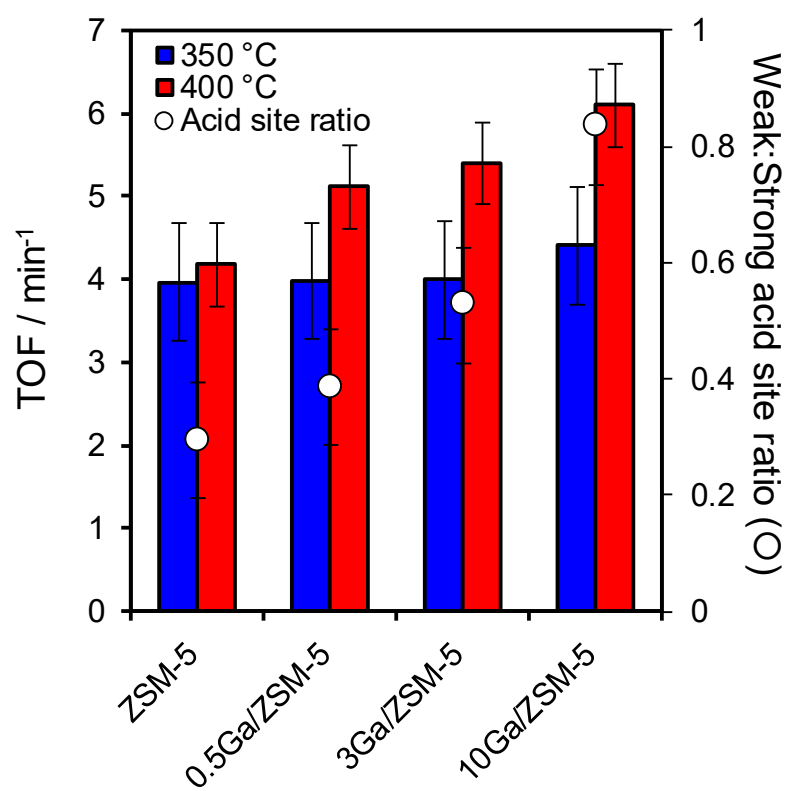

Figure 5. Turnover frequencies (TOFs) for acetic acid ketonisation over $x \mathrm{Ga} / \mathrm{HZSM}-5$ and corresponding weak:strong acid site ratio. Reaction conditions: $200 \mathrm{mg}$ catalyst, $0.2 \mathrm{~mL} \cdot \mathrm{min}^{-1}$ acetic acid, $50 \mathrm{~mL} \cdot \mathrm{min}^{-1}$ $\mathrm{N}_{2}, 1$ bar.

Acetone selectivity at iso-conversion increased with Ga loading at both $350{ }^{\circ} \mathrm{C}$ and $400{ }^{\circ} \mathrm{C}$ (Figure 6), concomitant with the rise in weak:strong acid site ratio and Lewis acidity [73]. Vervecken also reported an increase in acetone selectivity $>350^{\circ} \mathrm{C}$ for acetic acid ketonisation over HZSM-5(100) [42], attributed to a higher activation energy for ketonisation that competing aromatisation (which forms xylenols, phenolics and other aromatics). The maximum acetone selectivity for $10 \mathrm{Ga} / \mathrm{HZSM}-5$ was $30 \%$; the principal by-products were $\mathrm{CO}_{2}$, xylenol, phenol and hydrocarbons [42]. The observation that weak Lewis acid sites and/or related acid-base pairs are the active species for vapour phase acetic acid ketonisation (Figure S8) is consistent with previous experimental [74-77] and computational studies [72]. As discussed in the Introduction, acidic protons in zeolites promote the formation of surface acyl species, which may couple with carboxylate species formed over weaker acid sites to yield an acid anhydride intermediate which in turn decomposes to liberate $\mathrm{CO}_{2}$ and acetone [25]. However, Chang et al report that ketonisation over HZSM- 5 occurs via nucleophilic attack of an acylium ion by carboxylate species [48]; the acylium ion being formed by acid protonation and dehydration [48]. In the case of $\mathrm{xGa} / \mathrm{HZSM}-5$, Ga loadings $>10 \mathrm{wt} \%$ may further increase acetone productivity (and to a lesser extent selectivity) at lower reaction temperature. Although all $\times \mathrm{Ga} / \mathrm{HZSM}-5$ catalysts were stable for $5 \mathrm{~h}$ on-stream at $400{ }^{\circ} \mathrm{C}$, future extended ageing and recycling tests are required to optimise formulation and performance. 


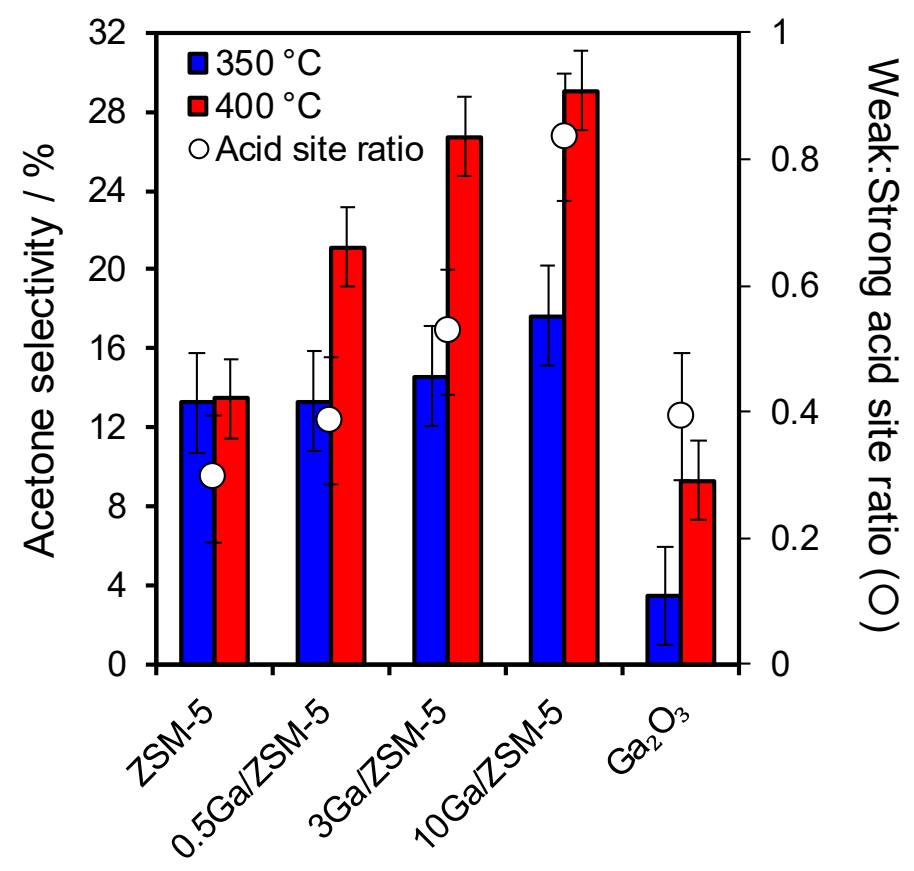

Figure 6. Correlation between acetone selectivity from acetic acid ketonisation at iso-conversion (23\% and $29 \%$ at $350{ }^{\circ} \mathrm{C}$ and $400{ }^{\circ} \mathrm{C}$, respectively) and weak:strong acid site ratio for $\mathrm{xGa} / \mathrm{HZSM}-5$. Reaction conditions: $200 \mathrm{mg}$ catalyst, $0.2 \mathrm{~mL} \cdot \mathrm{min}^{-1}$ acetic acid, $50 \mathrm{~mL} \cdot \mathrm{min}^{-1} \mathrm{~N}_{2}, 1$ bar.

\section{Materials and Methods}

\subsection{Catalyst Synthesis}

A commercial HZSM-5 $\left(\mathrm{SiO}_{2}: \mathrm{Al}_{2} \mathrm{O}_{3}=30\right.$, Zeolyst International, CBV 3024E) was first calcined in air at $550{ }^{\circ} \mathrm{C}$ for $4 \mathrm{~h}$ to remove any surface residues. Then $3 \mathrm{~g}$ of calcined HZSM- 5 was subsequently wet-impregnated with appropriate concentrations of a $20 \mathrm{~mL}$ aqueous solution of $\mathrm{Ga}\left(\mathrm{NO}_{3}\right)_{3} \cdot \mathrm{xH}_{2} \mathrm{O}$ (crystalline, 99.9\% trace metals basis, Sigma-Aldrich, UK) to prepare Ga gallium zeolites with nominal loadings of $0.5 \mathrm{wt} \%(0.005 \mathrm{M}), 3 \mathrm{wt} \%(0.03 \mathrm{M})$ and $10 \mathrm{wt} \%(0.1 \mathrm{M})$. In each case the resulting slurry was stirred for $6 \mathrm{~h}$ at ambient temperature, dried overnight at $90{ }^{\circ} \mathrm{C}$, and finally calcined at $500{ }^{\circ} \mathrm{C}$ under static for $4 \mathrm{~h}$. The resulting catalysts were designated $\mathrm{xGa} / \mathrm{HZSM}-5$ where $\mathrm{x}$ is the nominal Ga loading. Bulk $\mathrm{Ga}_{2} \mathrm{O}_{3}\left(\geq 99.99 \%\right.$ trace metals basis, Sigma-Aldrich, UK) was also calcined at $500{ }^{\circ} \mathrm{C}$ for $4 \mathrm{~h}$ as a reference material.

\subsection{Catalyst Characterisation}

The bulk Ga loading was determined by elemental analysis using a Thermofisher iCAP 7000 ICP-OES (Thermofisher, UK). Identification of crystalline phases was performed using a Bruker D8 Advance powder X-ray diffractometer (Bruker, UK) with $\mathrm{Cu} \mathrm{K}_{\alpha}$ radiation for angles between $2 \theta=10-80^{\circ}$ with a step size of $0.04^{\circ}$. Volume averaged particle sizes were estimated from the Scherrer equation using the peak width of characteristic HZSM- 5 and $\mathrm{Ga}_{2} \mathrm{O}_{3}$ reflections at $2 \theta=14.8^{\circ}$ and $35.2^{\circ}$ respectively. Surface areas, pore size distributions and mesopore volumes were determined by $\mathrm{N}_{2}$ porosimetry using a Quantasorb Nova 4000 e porosimeter and Novawin 11.03 software (Quantachrome, UK). Samples were outgassed in vacuo at $300^{\circ} \mathrm{C}$ for $18 \mathrm{~h}$ according to Quantachrome recommendations for microporous zeolites prior to analysis, with specific surface areas calculated by applying the Brunauer-Emmet-Teller (BET) model over the range $\mathrm{P} / \mathrm{P}_{0}=0.02-0.07$ of the adsorption isotherm. Micropore volumes were determined using the $\mathrm{t}$-plot method developed by Lippens and de Boer over the range $\mathrm{P} / \mathrm{P}_{0}=0.2-0.5$. X-ray photoelectron spectroscopy (XPS) measurements were performed using a Kratos Axis HSi photoelectron spectrometer (Kratos Analytical, UK) equipped with a charge neutraliser and a monochromated $\mathrm{Al} \mathrm{K}_{\alpha} \mathrm{X}$-ray source $(\mathrm{h} v=1486.7 \mathrm{eV})$. Spectra were recorded using 
an analyser pass energy of $20 \mathrm{eV}$ and X-ray power of $225 \mathrm{~W}$ at a normal emission. Spectral fitting was performed using CasaXPS version 2.3.14 (Casa Software Ltd, UK), with binding energies corrected to the $\mathrm{C} 1$ s peak at $284.6 \mathrm{eV}$; high resolution $\mathrm{C}$ and $\mathrm{O} 1 \mathrm{~s}, \mathrm{Ga}$, $\mathrm{Al}$ and $\mathrm{Si} 2 \mathrm{p} \mathrm{XP}$ spectra fitted using a common Gaussian/Lorentzian line shape. Spectra were Shirley background-subtracted and surface compositions quantified by application of element- and instrument-specific response factors. Errors in surface composition were estimated by varying the background subtraction procedure across reasonable limits and re-calculating fits. The carbon content of spent catalysts was measured using a Thermo Scientific Flash 2000 organic elemental analyser (Thermofisher, UK) calibrated to sulfanilamide, fitted with a $\mathrm{Cu} / \mathrm{CuO} \mathrm{CHNS}$ quartz tube and a thermal conductivity detector. Samples were prepared by adding $\sim 10 \mathrm{mg}$ catalyst and $\sim 2 \mathrm{mg} \mathrm{V}_{2} \mathrm{O}_{5}$ to tin crucibles.

Acid site loadings and strength were determined by n-propylamine (Sigma Aldrich, UK, $\geq 99 \%$ ) temperature-programmed reaction spectroscopy (TPRS) using a Mettler Toledo TGA/DSC 2 STARe system (Mettler Toledo, UK) connected to a Pfeiffer Vacuum ThermoStar GSD 301 T3 (Pfeiffer, UK) benchtop mass spectrometer (MS). Propylamine adsorption was performed by adding liquid n-propylamine to pre-weighed samples $(1 \mathrm{~mL}$ per $20 \mathrm{mg})$ and placing in an alumina crucible. Excess physisorbed propylamine was removed by drying in vacuo at $30^{\circ} \mathrm{C}$ for $1 \mathrm{~h}$ prior to analysis. Samples were heated in the thermogravimetric analyser (TGA) from $40^{\circ} \mathrm{C}$ to $800^{\circ} \mathrm{C}$ at a ramp rate of $10^{\circ} \mathrm{C} \cdot \mathrm{min}^{-1}$ under flowing $\mathrm{N}_{2}\left(40 \mathrm{~mL} \cdot \mathrm{min}^{-1}\right)$, with evolved gases analysed by MS to monitor reactively formed propene. Lewis/Brønsted character was determined by diffuse reflectance infrared Fourier transform spectroscopy (DRIFTS) of samples following pyridine adsorption over diluted samples $(10 \mathrm{wt} \%$ in $\mathrm{KBr})$. Excess physisorbed pyridine was removed in vacuo at $30^{\circ} \mathrm{C}$ overnight prior to room temperature measurement using a Nicolet Avatar 370 MCT (Thermofisher, UK) with Smart Collector accessory and liquid nitrogen cooled mercury cadmium telluride (MCT-A) detector. DRIFTS spectra were background-subtracted, and the ratio of the transmitted intensities of the $1450 \mathrm{~cm}^{-1}$ and $1540 \mathrm{~cm}^{-1}$ peaks used to quantify the ratio between Lewis and Brønsted acid sites.

\subsection{Catalytic Ketonisation}

Acetic acid ketonisation was performed in a bespoke continuous flow packed-bed reactor with online gas chromatography (GC) analysis. The reactor comprised a $1 \mathrm{~cm}$ o.d., quartz tube, within which the catalyst bed was placed centrally and retained by quartz wool plugs. A constant catalyst bed volume of $4 \mathrm{~cm}^{3}$ was used in all experiments, comprised of $200 \mathrm{mg}$ of catalyst diluted with fused silica granules. The reactor tube was positioned in a temperature-programmable furnace with a thermocouple placed in contact with the catalyst bed. Acetic acid (Sigma-Aldrich, UK, ACS reagent $\geq$ 99.7\%) was fed in a down-flow fashion into the reactor using an Agilent 1260 Infinity Isocratic Pump (Agilent, $\mathrm{UK}$ ) and $\mathrm{N}_{2}$ as the carrier gas $\left(50 \mathrm{~mL} \cdot \mathrm{min}^{-1}\right)$. All reactor lines were heated to $130{ }^{\circ} \mathrm{C}$ to prevent condensation, and a $1 \mathrm{~cm}$ diameter metal tube packed with fused silica granules was used to ensure acetic acid vaporisation before the reactor. Products were analysed online by a Varian 3800 GC (Varian, UK) with heated gas-sampling valve, equipped with a BR-Q PLOT column ( $30 \mathrm{~m} \times 0.53$ $\mathrm{mm}$ i.d.,). Acetone and acetic acid were detected using a flame ionisation detector (FID). The GC was calibrated for acetic acid and acetone by triplicate injections of $50 \mu \mathrm{l}$ standard solutions through a split/splitless injector. Acetic acid conversion and selectivity were calculated according to Equations (1) and (2).

$$
\begin{aligned}
& \text { Conversion }=\frac{\mathrm{n}_{\mathrm{AcOH}_{0}}-\mathrm{n}_{\mathrm{AcOH}}}{\mathrm{n}_{\mathrm{AcOH}}} \times 100 \\
& \text { Selectivity }=\frac{2 \times \mathrm{n}_{\mathrm{Acetone}}}{\mathrm{n}_{\mathrm{AcOH}}-\mathrm{n}_{\mathrm{AcOH}}} \times 100
\end{aligned}
$$

where $\mathrm{n}_{\mathrm{AcOH}_{0}}$ is the initial moles of acetic acid, $\mathrm{n}_{\mathrm{AcOH}}$ is the final moles acetic acid and $\mathrm{n}_{\text {Acetone }}$ represents the moles of produced as acetone. Acetone was the primary product over all catalysts. No acetic acid conversion was observed in the absence of a catalyst. 


\section{Conclusions}

A family of Ga-doped HZSM-5 materials were synthesis by wet impregnation as solid acid catalysts for the vapour phase ketonisation of acetic acid, a potential route to upgrading pyrolysis bio-oil vapours. XRD indicates that $\mathrm{Ga}$ is either incorporated into the parent zeolite framework or highly dispersed across the zeolite surface as $\mathrm{GaO}^{+}$clusters for loadings spanning $0.3-10 \mathrm{wt} \% \mathrm{Ga}$ doping has little impact on the zeolite textural properties but increased the Lewis acid character concomitant with a decrease in acid strength relative to HZSM-5. Turnover frequencies for acetic acid ketonisation, and acetone selectivity at iso-conversion, were both proportional to the weak:strong acid site ratio, evidencing that ketonisation over $\mathrm{xGa} / \mathrm{HZSM}-5$ preferentially occurs over weak (Lewis) acid sites. The most active catalyst was $10 \mathrm{wt} \% \mathrm{Ga} / \mathrm{HZSM}-5$, which was stable for $5 \mathrm{~h}$ on-stream despite significant carbon laydown, with an acetone selectivity of $30 \%$. Acetic acid ketonisation is an attractive route to upgrading biomass pyrolysis vapours through close-coupling with $\mathrm{Ga} / \mathrm{HZSM}-5$ catalysts derived from earth abundant elements.

Supplementary Materials: The following are available online at http://www.mdpi.com/2073-4344/9/10/841/s1, Figure S1: XRD patterns of $x \mathrm{Ga} / \mathrm{HZSM}-5$ and bulk $\mathrm{Ga}_{2} \mathrm{O}_{3}$; Figure $\mathrm{S} 2: \mathrm{N}_{2}$ adsorption-desorption isotherms of xGa/HZSM-5 and $\mathrm{Ga}_{2} \mathrm{O}_{3}$; Figure S3: (a) Al 2p and (b) Si $2 \mathrm{p}$ XP spectra of xGa/HZSM-5; Figure S4: (a) DRIFT spectra of pyridine-saturated $x \mathrm{Ga} / \mathrm{HZSM}-5$ and $\mathrm{Ga}_{2} \mathrm{O}_{3}$ and (b) corresponding Lewis:Brønsted acid site ratio (1444 cm $\mathrm{cm}^{-1}: 1545 \mathrm{~cm}^{-1}$ bands) for xGa/HZSM-5; Figure S5: Density of strong and weak acid sites for xGa/HZSM-5 from propylamine TPRS; Figure S6: Acetic acid conversion over $x \mathrm{Ga} / \mathrm{HZSM}-5$, and $\mathrm{Ga}_{2} \mathrm{O}_{3}$ vs time on stream. Reaction conditions: $200 \mathrm{mg}$ catalyst, at $400{ }^{\circ} \mathrm{C}, 0.2 \mathrm{~mL} \cdot \mathrm{min}^{-1}$ acetic acid, $50 \mathrm{~mL} \cdot \mathrm{min}^{-1} \mathrm{~N}_{2}, 1$ bar; Figure S7: XRD patterns of (a) fresh and (b) post-reaction $x \mathrm{Ga} / \mathrm{HZSM}-5$ and $\mathrm{Ga}_{2} \mathrm{O}_{3}$; Figure S8: Correlation between acetone selectivity from acetic acid ketonisation at iso-conversion $\left(23 \%\right.$ and $29 \%$ at $350{ }^{\circ} \mathrm{C}$ and $400{ }^{\circ} \mathrm{C}$, respectively) and acid strength from propylamine temperature-programmed reaction spectroscopy (higher temperatures indicate weaker acidity) over $\times \mathrm{Ga} / \mathrm{HZSM}-5$, and $\mathrm{Ga}_{2} \mathrm{O}_{3}$; Table S1: Surface and bulk composition of $\times \mathrm{Ga} / \mathrm{HZSM}-5$ and $\mathrm{Ga}_{2} \mathrm{O}_{3}$; Table S2: Carbon content of used $x \mathrm{Ga} / \mathrm{HZSM}-5$ and $\mathrm{Ga}_{2} \mathrm{O}_{3}$ after 5 h reaction.

Author Contributions: Conceptualisation, A.H., A.F.L. and K.W.; Formal analysis, H.J., A.O., A.F.L. and K.W.; Investigation, H.J.; Methodology, H.J.; Supervision, M.O., A.H., A.F.L., K.W.; Writing-original draft, H.J., A.O. and M.O.; Writing-review \& editing, A.F.L. and K.W.

Funding: We thank the EPSRC (EP/K036548/2, EP/K014676/1, EP/N009924/1) for financial support. K.W. thanks the Royal Society for the award of an Industry Fellowship.

Conflicts of Interest: The authors declare no conflict of interest.

\section{References}

1. Wilson, K.; Lee, A.F. Catalyst design for biorefining. Philos. Trans. R. Soc. A 2016, 374, 20150081. [CrossRef]

2. Alonso, D.M.; Bond, J.Q.; Dumesic, J.A. Catalytic conversion of biomass to biofuels. Green Chem. 2010, 12, 1493-1513. [CrossRef]

3. Leitner, W.; Klankermayer, J.; Pischinger, S.; Pitsch, H.; Kohse-Höinghaus, K. Advanced Biofuels and Beyond: Chemistry Solutions for Propulsion and Production. Angew. Chem. Int. Ed. 2017, 56, 5412-5452. [CrossRef]

4. Toor, S.S.; Rosendahl, L.; Rudolf, A. Hydrothermal liquefaction of biomass: A review of subcritical water technologies. Energy 2011, 36, 2328-2342. [CrossRef]

5. Elliott, D.C.; Biller, P.; Ross, A.B.; Schmidt, A.J.; Jones, S.B. Hydrothermal liquefaction of biomass: Developments from batch to continuous process. Bioresour. Technol. 2015, 178, 147-156. [CrossRef]

6. Bridgwater, A.V. Review of fast pyrolysis of biomass and product upgrading. Biomass Bioenergy 2012, 38, 68-94. [CrossRef]

7. Santos, J.; Ouadi, M.; Jahangiri, H.; Hornung, A. Integrated intermediate catalytic pyrolysis of wheat husk. Food Bioprod. Process. 2019, 114, 23-30. [CrossRef]

8. Yung, M.M.; Jablonski, W.S.; Magrini-Bair, K.A. Review of Catalytic Conditioning of Biomass-Derived Syngas. Energy Fuels 2009, 23, 1874-1887. [CrossRef]

9. Ouadi, M.; Fivga, A.; Jahangiri, H.; Saghir, M.; Hornung, A. A Review of the Valorization of Paper Industry Wastes by Thermochemical Conversion. Ind. Eng. Chem. Res. 2019, 58, 15914-15929. [CrossRef] 
10. Jahangiri, H.; Bennett, J.; Mahjoubi, P.; Wilson, K.; Gu, S. A review of advanced catalyst development for Fischer-Tropsch synthesis of hydrocarbons from biomass derived syn-gas. Catal. Sci. Technol. 2014, 4, 2210-2229. [CrossRef]

11. Sartipi, S.; Makkee, M.; Kapteijn, F.; Gascon, J. Catalysis engineering of bifunctional solids for the one-step synthesis of liquid fuels from syngas: A review. Catal. Sci. Technol. 2014, 4, 893-907. [CrossRef]

12. Hassan, H.; Lim, J.K.; Hameed, B.H. Recent progress on biomass co-pyrolysis conversion into high-quality bio-oil. Bioresour. Technol. 2016, 221, 645-655. [CrossRef] [PubMed]

13. Papari, S.; Hawboldt, K. A review on the pyrolysis of woody biomass to bio-oil: Focus on kinetic models. Renew. Sustain. Energy Rev. 2015, 52, 1580-1595. [CrossRef]

14. Sfetsas, T.; Michailof, C.; Lappas, A.; Li, Q.; Kneale, B. Qualitative and quantitative analysis of pyrolysis oil by gas chromatography with flame ionization detection and comprehensive two-dimensional gas chromatography with time-of-flight mass spectrometry. J. Chromatogr. A 2011, 1218, 3317-3325. [CrossRef]

15. Ciddor, L.; Bennett, J.A.; Hunns, J.A.; Wilson, K.; Lee, A.F. Catalytic upgrading of bio-oils by esterification. J. Chem. Technol. Biotechnol. 2015, 90, 780-795. [CrossRef]

16. Pirez, C.; Caderon, J.-M.; Dacquin, J.-P.; Lee, A.F.; Wilson, K. Tunable KIT-6 Mesoporous Sulfonic Acid Catalysts for Fatty Acid Esterification. ACS Catal. 2012, 2, 1607-1614. [CrossRef]

17. Zacher, A.H.; Olarte, M.V.; Santosa, D.M.; Elliott, D.C.; Jones, S.B. A review and perspective of recent bio-oil hydrotreating research. Green Chem. 2014, 16, 491-515. [CrossRef]

18. Snell, R.W.; Combs, E.; Shanks, B.H. Aldol Condensations Using Bio-oil Model Compounds: The Role of Acid-Base Bi-functionality. Top. Catal. 2010, 53, 1248-1253. [CrossRef]

19. Jahangiri, H.; Osatiashtiani, A.; Bennett, J.A.; Isaacs, M.A.; Gu, S.; Lee, A.F.; Wilson, K. Zirconia catalysed acetic acid ketonisation for pre-treatment of biomass fast pyrolysis vapours. Catal. Sci. Technol. 2018, 8, 1134-1141. [CrossRef]

20. Manayil, J.C.; Inocencio, C.V.; Lee, A.F.; Wilson, K. Mesoporous sulfonic acid silicas for pyrolysis bio-oil upgrading via acetic acid esterification. Green Chem. 2016, 18, 1387-1394. [CrossRef]

21. Marker, T.L.; Felix, L.G.; Linck, M.B.; Roberts, M.J. Integrated hydropyrolysis and hydroconversion (IH 2) for the direct production of gasoline and diesel fuels or blending components from biomass, part 1: Proof of principle testing. Environ. Prog. Sustain. Energy 2012, 31, 191-199. [CrossRef]

22. Bennett, J.A.; Parlett, C.M.A.; Isaacs, M.A.; Durndell, L.J.; Olivi, L.; Lee, A.F.; Wilson, K. Acetic Acid Ketonization over $\mathrm{Fe}_{3} \mathrm{O}_{4} / \mathrm{SiO}_{2}$ for Pyrolysis Bio-Oil Upgrading. ChemCatChem 2017, 9, 1648-1654. [CrossRef]

23. Pham, T.N.; Shi, D.; Resasco, D.E. Kinetics and Mechanism of Ketonization of Acetic Acid on Ru/TiO2 Catalyst. Top. Catal. 2014, 57, 706-714. [CrossRef]

24. Heracleous, E.; Gu, D.; Schüth, F.; Bennett, J.A.; Isaacs, M.A.; Lee, A.F.; Wilson, K.; Lappas, A.A. Bio-oil upgrading via vapor-phase ketonization over nanostructured $\mathrm{FeO} x$ and $\mathrm{MnO}$ : Catalytic performance and mechanistic insight. Biomass Convers. Biorefinery 2017, 7, 319-329. [CrossRef]

25. Pham, T.N.; Sooknoi, T.; Crossley, S.P.; Resasco, D.E. Ketonization of Carboxylic Acids: Mechanisms, Catalysts, and Implications for Biomass Conversion. ACS Catal. 2013, 3, 2456-2473. [CrossRef]

26. Gaertner, C.A.; Serrano-Ruiz, J.C.; Braden, D.J.; Dumesic, J.A. Ketonization Reactions of Carboxylic Acids and Esters over Ceria-Zirconia as Biomass-Upgrading Processes. Ind. Eng. Chem. Res. 2010, 49, 6027-6033. [CrossRef]

27. Wortz, C.G. Process for the Production of Ketones. U.S. Patent 2,108,156, 15 February 1938.

28. Nagashima, O.; Sato, S.; Takahashi, R.; Sodesawa, T. Ketonization of carboxylic acids over CeO2-based composite oxides. J. Mol. Catal. A Chem. 2005, 227, 231-239. [CrossRef]

29. Pestman, R.; Koster, R.M.; van Duijne, A.; Pieterse, J.A.Z.; Ponec, V. Reactions of carboxylic acids on oxides. 2. Bimolecular reaction of aliphatic acids to ketones. J. Catal. 1997, 168, 265-272. [CrossRef]

30. Gliński, M.; Kijeński, J. Catalytic Ketonization of Carboxylic Acids Synthesis of Saturated and Unsaturated Ketones. React. Kinet. Catal. Lett. 2000, 69, 123-128. [CrossRef]

31. Parida, K.M.; Samal, A.; Das, N.N. Catalytic ketonization of monocarboxylic acids over Indian Ocean manganese nodules. Appl. Catal. A Gen. 1998, 166, 201-205. [CrossRef]

32. Martinez, R.; Huff, M.C.; Barteau, M.A. Ketonization of acetic acid on titania-functionalized silica monoliths. J. Catal. 2004, 222, 404-409. [CrossRef] 
33. Kim, K.S.; Barteau, M.A. Structure and Composition Requirements for Deoxygenation, Dehydration, and Ketonization Reactions of Carboxylic-Acids on Tio2 (001) Single-Crystal Surfaces. J. Catal. 1990, 125, 353-375. [CrossRef]

34. Pestman, R.; Koster, R.M.; Pieterse, J.A.Z.; Ponec, V. Reactions of carboxylic acids on oxides. 1. Selective hydrogenation of acetic acid to acetaldehyde. J. Catal. 1997, 168, 255-264. [CrossRef]

35. Randery, S.D.; Warren, J.S.; Dooley, K.M. Cerium oxide-based catalysts for production of ketones by acid condensation. Appl. Catal. A Gen. 2002, 226, 265-280. [CrossRef]

36. Dooley, K.M.; Bhat, A.K.; Plaisance, C.P.; Roy, A.D. Ketones from acid condensation using supported CeO2 catalysts: Effect of additives. Appl. Catal. A Gen. 2007, 320, 122-133. [CrossRef]

37. Gliński, M.; Kijeński, J. Decarboxylative coupling of heptanoic acid. Manganese, cerium and zirconium oxides as catalysts. Appl. Catal. A Gen. 2000, 190, 87-91.

38. Okumura, K.; Iwasawa, Y. Zirconium Oxides Dispersed on Silica Derived from $\mathrm{Cp} 2 \mathrm{ZrCl} 2$, $[(\mathrm{i}-\mathrm{PrCp}) 2 \mathrm{ZrH}(\mu-\mathrm{H})] 2$, and $\mathrm{Zr}(\mathrm{OEt}) 4$ Characterized by X-Ray Absorption Fine Structure and Catalytic Ketonization of Acetic Acid. J. Catal. 1996, 164, 440-448. [CrossRef]

39. Kistler, S.S.; Swann, S.; Appel, E.G. Aërogel Catalysts-Thoria: Preparation of Catalyst and Conversions of Organic Acids to Ketones. Ind. Eng. Chem. 1934, 26, 388-391. [CrossRef]

40. Pacchioni, G. Ketonization of Carboxylic Acids in Biomass Conversion over TiO2 and ZrO2 Surfaces: A DFT Perspective. ACS Catal. 2014, 4, 2874-2888. [CrossRef]

41. Patil, K.C.; Chandrashekhar, G.V.; George, M.V.; Rao, C.N.R. Infrared spectra and thermal decompositions of metal acetates and dicarboxylates. Can. J. Chem. 1968, 46, 257-265. [CrossRef]

42. Vervecken, M.; Servotte, Y.; Wydoodt, M.; Jacobs, L.; Martens, J.A.; Jacobs, P.A. Zeolite-Induced Selectivity in the Conversion of the Lower Aliphatic Carboxylic Acids. In Chemical Reactions in Organic and Inorganic Constrained Systems; Setton, R., Ed.; Springer: Dordrecht, The Netherlands, 1986; pp. 95-114.

43. Iliopoulou, E.F.; Stefanidis, S.D.; Kalogiannis, K.G.; Delimitis, A.; Lappas, A.A.; Triantafyllidis, K.S. Catalytic upgrading of biomass pyrolysis vapors using transition metal-modified ZSM-5 zeolite. Appl. Catal. B-Environ. 2012, 127, 281-290. [CrossRef]

44. French, R.; Czernik, S. Catalytic pyrolysis of biomass for biofuels production. Fuel Process. Technol. 2010, 91, 25-32. [CrossRef]

45. Neumann, G.T.; Hicks, J.C. Effects of Cerium and Aluminum in Cerium-Containing Hierarchical HZSM-5 Catalysts for Biomass Upgrading. Top. Catal. 2012, 55, 196-208. [CrossRef]

46. Cheng, Y.T.; Jae, J.; Shi, J.; Fan, W.; Huber, G.W. Production of Renewable Aromatic Compounds by Catalytic Fast Pyrolysis of Lignocellulosic Biomass with Bifunctional Ga/ZSM-5 Catalysts. Angew. Chem. Int. Ed. 2012, 51, 1387-1390. [CrossRef] [PubMed]

47. Gumidyala, A.; Sooknoi, T.; Crossley, S. Selective ketonization of acetic acid over HZSM-5: The importance of acyl species and the influence of water. J. Catal. 2016, 340, 76-84. [CrossRef]

48. Chang, C.D.; Chen, N.Y.; Koenig, L.R.; Walsh, D.E. Synergism in Acetic-Acid Methanol Reactions over Zsm-5 Zeolites. Abstr. Pap. Am. Chem. Soc. 1983, 185, 49-Fuel.

49. Tessonnier, J.-P.; Louis, B.; Walspurger, S.; Sommer, J.; Ledoux, M.-J.; Pham-Huu, C. Quantitative Measurement of the Brönsted Acid Sites in Solid Acids: Toward a Single-Site Design of Mo-Modified ZSM-5 Zeolite. J. Phys. Chem. B 2006, 110, 10390-10395. [CrossRef]

50. Li, B.; Li, S.; Li, N.; Chen, H.; Zhang, W.; Bao, X.; Lin, B. Structure and acidity of Mo/ZSM-5 synthesized by solid state reaction for methane dehydrogenation and aromatization. Microporous Mesoporous Mater. 2006, 88, 244-253. [CrossRef]

51. Fang, Y.; Su, X.; Bai, X.; Wu, W.; Wang, G.; Xiao, L.; Yu, A. Aromatization over nanosized Ga-containing ZSM-5 zeolites prepared by different methods: Effect of acidity of active Ga species on the catalytic performance. J. Energy Chem. 2017, 26, 768-775. [CrossRef]

52. Amin, N.A.S.; Ali, A. Characterization of Modified HZSM-5 with Gallium and its Reactivity in Direct Conversion of Methane to Liquid Hydrocarbons. J. Teknol. 2001, 35, 21-30.

53. Li, J.Y.; Chen, X.L.; Qiao, Z.Y.; He, M.; Li, H. Large-scale synthesis of single-crystalline beta-Ga2O3 nanoribbons, nanosheets and nanowires. J. Phys. Condens. Matter 2001, 13, L937-L941. [CrossRef]

54. Huang, C.-C.; Yeh, C.-S. GaOOH, and [small beta]- and [gamma]-Ga2O3 nanowires: Preparation and photoluminescence. New J. Chem. 2010, 34, 103-107. [CrossRef] 
55. Wang, S.; Yin, Q.; Guo, J.; Ru, B.; Zhu, L. Improved Fischer-Tropsch synthesis for gasoline over Ru, Ni promoted Co/HZSM-5 catalysts. Fuel 2013, 108, 597-603. [CrossRef]

56. Rodrigues, V.D.; Eon, J.G.; Faro, A.C. Correlations between Dispersion, Acidity, Reducibility, and Propane Aromatization Activity of Gallium Species Supported on HZSM5 Zeolites. J. Phys. Chem. C 2010, 114, 4557-4567. [CrossRef]

57. Tamba, D.; Kubo, O.; Oda, M.; Osaka, S.; Takahashi, K.; Tabata, H.; Kaneko, K.; Fujita, S.; Katayama, M. Surface termination structure of $\alpha-\mathrm{Ga} 2 \mathrm{O} 3$ film grown by mist chemical vapor deposition. Appl. Phys. Lett. 2016, 108, 251602. [CrossRef]

58. Grunert, W.; Muhler, M.; Schroder, K.P.; Sauer, J.; Schlogl, R. Investigations of Zeolites by Photoelectron and Ion-Scattering Spectroscopy.2. A New Interpretation of Xps Binding-Energy Shifts in Zeolites. J. Phys. Chem. 1994, 98, 10920-10929. [CrossRef]

59. Borade, R.B.; Clearfield, A. Characterization of Acid Sites in Beta and Zsm-20 Zeolites. J. Phys. Chem. 1992, 96, 6729-6737. [CrossRef]

60. Guo, D.; Wu, Z.; An, Y.; Li, P.; Wang, P.; Chu, X.; Guo, X.; Zhi, Y.; Lei, M.; Li, L. Unipolar resistive switching behavior of amorphous gallium oxide thin films for nonvolatile memory applications. Appl. Phys. Lett. 2015, 106, 042105. [CrossRef]

61. Wei, W.; Qin, Z.; Fan, S.; Li, Z.; Shi, K.; Zhu, Q.; Zhang, G. Valence band offset of $\beta$-Ga2O3/wurtzite GaN heterostructure measured by X-ray photoelectron spectroscopy. Nanoscale Res. Lett. 2012, 7, 1-5. [CrossRef]

62. Xiao, H.; Zhang, J.F.; Wang, X.X.; Zhang, Q.D.; Xie, H.J.; Han, Y.Z.; Tan, Y.S. A highly efficient Ga/ZSM-5 catalyst prepared by formic acid impregnation and in situ treatment for propane aromatization. Catal. Sci. Technol. 2015, 5, 4081-4090. [CrossRef]

63. Carli, R.; Bianchi, C.L. Xps Analysis of Gallium Oxides. Appl. Surf. Sci. 1994, 74, 99-102. [CrossRef]

64. Altwasser, S.; Raichle, A.; Traa, Y.; Weitkamp, J. Preparation of gallium-containing catalysts by solid-state reaction of acidic Zeolites with elemental gallium. Chem. Eng. Technol. 2004, 27, 1262-1265. [CrossRef]

65. Anunziata, O.A.; Pierella, L.B. Nature of the Active-Sites in H-Zsm-11 Zeolite Modified with $\mathrm{Zn}^{(2+)}$ and $\mathrm{Ga}^{(3+)}$. Catal. Lett. 1993, 19, 143-151. [CrossRef]

66. Lavalley, J.C.; Daturi, M.; Montouillout, V.; Clet, G.; Arean, C.O.; Delgado, M.R.; Sahibed-dine, A. Unexpected similarities between the surface chemistry of cubic and hexagonal gallia polymorphs. Phys. Chem. Chem. Phys. 2003, 5, 1301-1305. [CrossRef]

67. Vimont, A.; Lavalley, J.C.; Sahibed-Dine, A.; Arean, C.O.; Delgado, M.R.; Daturi, M. Infrared spectroscopic study on the surface properties of gamma-gallium oxide as compared to those of gamma-alumina. J. Phys. Chem. B 2005, 109, 9656-9664. [CrossRef] [PubMed]

68. Phumman, P.; Niamlang, S.; Sirivat, A. Fabrication of Poly(p-Phenylene)/Zeolite Composites and Their Responses Towards Ammonia. Sensors 2009, 9, 8031-8046. [CrossRef]

69. Morterra, C.; Cerrato, G.; Ferroni, L.; Negro, A.; Montanaro, L. Surface characterization of tetragonal ZrO2. Appl. Surf. Sci. 1993, 65, 257-264. [CrossRef]

70. Dompas, D.H.; Mortier, W.J.; Kenter, O.C.H.; Janssen, M.J.G.; Verduijn, J.P. The influence of framework-gallium in zeolites: Electronegativity and infrared spectroscopic study. J. Catal. 1991, 129, 19-24. [CrossRef]

71. Pulido, A.; Oliver-Tomas, B.; Renz, M.; Boronat, M.; Corma, A. Ketonic Decarboxylation Reaction Mechanism: A Combined Experimental and DFT Study. ChemSusChem 2013, 6, 141-151. [CrossRef]

72. Wang, S.; Iglesia, E. Experimental and Theoretical Evidence for the Reactivity of Bound Intermediates in Ketonization of Carboxylic Acids and Consequences of Acid-Base Properties of Oxide Catalysts. J. Phys. Chem. C 2017, 121, 18030-18046. [CrossRef]

73. Schreiber, M.W.; Plaisance, C.P.; Baumgartl, M.; Reuter, K.; Jentys, A.; Bermejo-Deval, R.; Lercher, J.A. Lewis-Bronsted Acid Pairs in Ga/H-ZSM-5 To Catalyze Dehydrogenation of Light Alkanes. J. Am. Chem. Soc. 2018, 140, 4849-4859. [CrossRef] [PubMed]

74. Mattsson, A.; Österlund, L. Adsorption and Photoinduced Decomposition of Acetone and Acetic Acid on Anatase, Brookite, and Rutile TiO2 Nanoparticles. J. Phys. Chem. C 2010, 114, 14121-14132. [CrossRef]

75. Ma, Q.; Liu, Y.; Liu, C.; He, H. Heterogeneous reaction of acetic acid on $\mathrm{MgO}$, [small alpha]- $\mathrm{Al}_{2} \mathrm{O}_{3}$, and $\mathrm{CaCO}_{3}$ and the effect on the hygroscopic behaviour of these particles. Phys. Chem. Chem. Phys. 2012, 14, 8403-8409. [CrossRef] [PubMed] 
76. Finocchio, E.; Willey, R.J.; Busca, G.; Lorenzelli, V. FTIR studies on the selective oxidation and combustion of light hydrocarbons at metal oxide surfaces Part 3.-Comparison of the oxidation of $\mathrm{C} 3$ organic compounds over Co3O4, MgCr2O4 and CuO, Journal of the Chemical Society. Faraday Trans. 1997, 93, 175-180. [CrossRef]

77. Geiculescu, A.C.; Spencer, H.G. Thermal Decomposition and Crystallization of Aqueous Sol-Gel Derived Zirconium Acetate Gels: Effects of the Additive Anions. J. Sol-Gel Sci. Technol. 2000, 17, 25-35. [CrossRef]

(C) 2019 by the authors. Licensee MDPI, Basel, Switzerland. This article is an open access article distributed under the terms and conditions of the Creative Commons Attribution (CC BY) license (http://creativecommons.org/licenses/by/4.0/). 